devices in which the electron plays an essential part, and to show the important part these developments play in modern daily life. The exhibits will range from Thomson's original apparatus to the most modern developments, such as the electron microscope. A handbook has been specially written by Mr. D. H. Follett, of the Science Museum (at the Museum, or from the Institute of Physics, 1s. $2 d$. post paid) ; the first part is a guide to the exhibition and the second is a general account of the subjects dealt with in the various sections of the exhibition.

\section{Hydrocyanic Acid and Poliomyelitis}

Poliomyelitis (infantile paralysis) in human beings is ordinarily regarded as an infectious disease caused by a virus. While it is true that a virus has been isolated and can be transmitted to monkeys, there are many features in the incidence of the disease which are difficult to reconcile with the virus hypothesis. The epidemiological features of the disease strongly suggest that food is concerned in its spread, but repeated attempts to demonstrate an infective agent in the food have failed. The occurrence of local outbreaks under certain seasonal and climatic conditions and the apparent absence of direct caseto-case transmission are suggestive of some form of food poisoning. R. R. Scobey (Archiv. Pediatrics, New York, 63, 322; 1946) puts forward the theory that the disease is primarily due to hydrocyanic acid poisoning; either the hydrocyanic acid directly poisons the nerve cells, or else it makes them susceptible to a virus which is normally about the body. Hydrocyanic acid, in the free state or in the form of mustard oil or cyanophore glucosides, is now known to be present in many of the vegetables and fruits which are ordinarily consumed during the time of year when poliomyelitis is prevalent. The plants concerned belong to the Cruciferæ (mustard, horseradish, cauliflower, cabbage) and Rosacer (most of the ordinary stone-fruits and berries). The symptoms and pathological changes which occur in experimental hydrocyanic acid poisoning in animals and in many of the recorded cases of poisoning in man bear a striking resemblance to those of poliomyelitis. The hydrocyanic acid content of plants shows a marked seasonal variation. The geographical distribution, seasonal incidence and climatic conditions observed during epidemics of poliomyelitis can be correlated with a high hydrocyanic acid content of the local flora and with the feeding habits of the community. Scobey brings together much circumstantial evidence in support of his theory, which will deserve serious attention, for this is a disastrous disease for which no rational therapy is at present available.

Immigration into Britain of Continental Butterflies

AUGust 1947 was marked by the large-scale immigration of certain Continental butterflies which are infrequent visitors in the British Isles. Most striking was the extensive arrival of the clouded yellow (Colias croceus Fourcrory), which ranged from southern England to Scotland, and included specimens of the pale greenish-white female variety helice, and a few of the scarcer pale clouded yellow (Colias hyales Linn.). Even more interesting was the appearance in the north of England of the Camberwell beauty (Nymphalis antiopa, Linn.) after an absence of many years. At a meeting of the Merseyside Naturalists' Association on August 24, A. J. Cobham reported the appearance of this insect at Maghull, Lancashire, the previous week, and afterwards a specimen was caught at Birkenhead, Cheshire. This insect migrates across the North Sea from its haunts in northern Europe, from Scandinavia to Germany and Holland, whereas the clouded yellow's migration route is from North Africa across France. 1941 was the last notable 'clouded yellow' year, the greatest immigration since 1877, while 1917 was remarkable for Camberwell beauties: the Camberwell beauty was first recorded in Cool Arbour Lane, Camberwell, London, in August 1748. There has also been a marked invasion of death's head hawk moths (Acherontia atropos Linn.) in the north of England, and numerous larvæ of these Continental moths were found in potato fields during August.

\section{Stanislaw Kalinowski and the Swider Geophysical Observatory}

No. 10 of the Travaux de l'Observatoire Géophysique a Swider, Poland, is the first publication of the Observatory for seven years; geophysicists will welcome this reappearance of the journal, more especially in view of the great sufferings of Poland during the War, and the continuing difficulties there. But they will mourn the loss, reported in this issue of the Travaux, of the founder and director of the Observatory, Stanislaw Kalinowski, whose death occurred early last year, at the age of seventy. Many who were present at the Edinburgh assembly of the International Union for Geodesy and Geophysics, which he attended with his daughter, will cherish recollections of his ardent interest in the science of geomagnetism, which he served so long and so well, particularly through the founding of the Swider Observatory in 1921, and through the magnetic survey of Poland which he conducted from that base. This issue of the Travaux, prepared by his hand, besides giving hourly values of the magnetic elements at Swider for the year 1936, summarizes the results obtained for the daily variation of the magnetic elements over the period 1921-35; it also contains a vivid account of the fortunes of the Observatory during the Second World War. An introduction to the publication, written by another hand, gives a moving account of his own heroic struggles, amidst afflictions that would have crushed many a younger man, to defend his Observatory from Nazi avidity and to maintain its work. $\mathrm{He}$ never lost faith in the overthrow of the conquerors of Poland, and made plans for the end of the War and the future of the Observatory. It is good to know that State provision has now been made for the Observatory, and that it has been newly named after its distinguished founder.

\section{A Fully Automatic Low-Temperature Cabinet}

J. and E. HaLl, LTD., of Dartford, Kent, have recently produced, for research purposes, a fully automatic low-temperature cabinet which can run at a temperature of $-95^{\circ} \mathrm{C}$. The manufacturers believe this to be the only plant available of this type, developed and manufactured entirely in Great Britain. The unit has been produced almost exclusively from normal standard equipment. Refrigeration is accomplished by the use of two small 'Hallmark' refrigerating compressors of conventional standard design which are arranged to run in cascade, suitable refrigerants being chosen for the high and low stages. The cooled cabinet consists of a cylindrical metal vessel, $19 \frac{1}{2}$ in. internal diameter by 36 in. high. The whole equipment is arranged on a chassis which can be easily moved from one laboratory 